\title{
Analysis of F-Canyon Effluents During the Dissolution Cycle with a Fourier Transform Infrared Spectrometer/Multipath Cell
}

by

E. Villa

Westinghouse Savannah River Company

Savannah River Site

Aiken, South Carolina 29808

DOE Contract No. DE-AC09-89SR18035

This paper was prepared in connection with work done under the above contract number with the U. S.

Department of Energy. By acceptance of this paper, the publisher and/or recipient acknowledges the U.S. Government's right to retain a nonexclusive, royalty-free license in and to any copyright covering this paper, along with the right to reproduce and to authorize others to reproduce all or part of the copyrighted paper. 


\section{DISCLAIMER}

This report was prepared as an account of work sponsored by an agency of the United States Government. Neither the United States Government nor any agency thereof, nor any of their employees, makes any warranty, express or implied, or assumes any legal liability or responsibility for the accuracy, completeness, or usefulness of any information, apparatus, product, or process disclosed, or represents that its use would not infringe privately owned rights. Reference herein to any specific commercial product, process, or service by trade name, trademark, manufacturer, or otherwise does not necessarily constitute or imply its endorsement, recommendation, or favoring by the United States Government or any agency thereof. The views and opinions of authors expressed herein do not necessarily state or reflect those of the United States Government or any agency thereof.

This report has been reproduced directly from the best available copy.

Available to DOE and DOE contractors from the Office of Scientific and Technical Information, P. O. Box 62, Oak Ridge, TN 37831; prices available from (423) 576-8401.

Available to the public from the National Technical Information Service, U. S. Department of Commerce, 5285 Port Royal Road, Springfield, VA 22161. 


\section{DISCLAIMER}

Portions of this document may be illegible in electronic image products. Images are produced from the best available original document. 


\section{Analysis of F-Canyon Effluents during the Dissolution Cycle with a Fourier Transform Infrared Spectrometer/Multipath Cell (U)}

Westinghouse Savannah River Company

Savannah River Site

Aiken, SC 29808

Prepared for the U.S. Department of Energy under contract no. DE-AC09-89SR18035 


\section{Analysis of F-Canyon Effluents during the Dissolution Cycle with a Fourier Transform Infrared Spectrometer/Multipath Cel I(U)}

E. Villa

Prepared for the U.S. Department of Energy under contract no. DE-ACO9-89SR18035 


\section{Abstract 1 \\ Introduction 1 \\ Experimental 1 \\ Discussion and Results 4 \\ Conclusion 10}

\section{List of Tables}

Table 1.

Table 2.

Table 3.

Decladding and dissolution process in conjunction with air bag collection sequence 2

Chemicals and their respective vibrational frequencies 4

Air sample concentration analysis (ppm). $\mathrm{Kr}-85$ is in dpm/cc of air. 8

\section{List of Figures}

Figure 1.

Figure 2.

Figure $3 a$ and $3 b$.

Figure 3c.

Figure 4.

Figure 5.

Figure 6.

Figure 7.

Figure 8.
FTIR spectromèter/multipath cell assembly 11

Absorption spectrum of WA7 Sample 12

Infrared absorption spectra of WA7 sample with spectroscopically removed and with background subtraction (WA5) 12

Amplification of small infrared absorption bands in Figure $3 \mathrm{~b} 13$ Simplified schematic of F-Canyon stack 13

Infrared absorption of spectra of $\mathrm{NO}_{2}, \mathrm{NO}, \mathrm{N}_{2} \mathrm{O}$, and $\mathrm{HNO}_{2} 14$

Three-dimensional plot (intensity-wavenumber-time) 14

Concentration plot v. time. $\mathrm{Kr}-85$ data is in disintegrations per minute per $\mathrm{ml}$ of air (dpm/cc) 15

Passive spectrum of ammonia (plume-sky) and library sequence 16 


\section{Abstract}

Air samples from F-Canyon effluents were collected at the F-Canyon stack and transported to a laboratory at the Savannah River Technology Center (SRTC) for analysis using a Fourier transform infrared spectrometer in conjunction with a multipath cell. Air samples were collected during the decladding and aciddissolution of the irradiated aluminum-cladded slugs. The FTIR analyses of the air samples show the presence of $\mathrm{NO}_{2}, \mathrm{NO}$, $\mathrm{HNO}_{2}$, and $\mathrm{N}_{2} \mathrm{O}$ during the dissolution cycle. Also $\mathrm{SF}_{6}$ that was inserted in the stack annulus as part of a tracer experiment was observed in the stack. The concentration time profiles of these effluents corresponded with expected release rates from the F-Canyon operations and correlated with measurements of ${ }^{\text {t5 }} \mathrm{Kr}$ made on the same air samples.

\section{Introduction}

F-Canyon restart offers a unique opportunity to identify organic and inorganic effluent signatures not previously studied and concentration profiles associated with the processes. The restart also offers the opportunity to develop nonproliferation technologies and methodologies to identify the gaseous effluents released to the atmosphere. F Canyon at the Savannah River Site (SRS) started processing irradiated aluminum-cladded uranium slugs on February 13, 1997. Since access to the stack was not possible before the November 3-8, 1996 dissolution, previous studies were conducted using a tethered balloon equipped with an air sampler for laboratory analysis and a Fourier transform infrared spectrometer operating in the passive mode.

The waste stabilization process on irradiated aluminum-cladded uranium slugs is similar to fuel reprocessing. The dissolution process occurs in three phases. In the first phase, the aluminum cladding is removed from the slugs with a 50-50\% $\mathrm{NaNO}_{3}$ and $\mathrm{NaOH}$ solution. Ammonia produced during the decladding process is released through one of the dissolver stacks attached to the main stack. The decladding phase is followed by the dissolution of the uranium slugs using $\mathrm{HNO}_{3}$. In this phase, large quantities of NOx are released to the stack. $\mathrm{NO}$ and $\mathrm{NO}_{2}$ are the major contributors in the gaseous plume. The third phase consists of extracting plutonium using tributyl phosphate (TBP) diluted in n-paraffin. Several hydrocarbons are expected to be released to the atmosphere during this phase.

During the past several years, improvements were made to the canyons to reduce NOx emissions. Previous dissolution of targets (prior 1990) were clearly identified by the brown plume emanating from the canyon stack. In contrast, present-day dissolutions are vaguely identifiable by a light brown haze over the stack. The weak appearance of the plume is the result of changes in operating procedures, modifications to the scrubbers, and the addition of ventilation fans.

Access to the main stack was available for dissolution \#9. Dissolution \#9 occurred during the week of November 3-8, 1996. The air samples extracted from the main stack provided the first glimpse of the inorganic effluents released to the atmosphere during the decladding and dissolution cycles. 


\section{Experimental}

During the week of November 3-8, 1996, the Nonproliferation Technologies Section was able to install a temporary air sampler in the main stack with multifunctional capabilities. One of the capabilities of the air sampler was to fill 5-liter Tedlar ${ }^{\mathrm{TM}}$ bags for analysis in the laboratory. The air bags were collected at predetermined times during the decladding and dissolution cycles.

F-Canyon personnel loaded the canyon with a 22 "bucket" charge corresponding to 14.7 metric ton units (MTU). Charge \#9 data is shown in Table 1 in conjunction with the air collection sequence (WA\# stands for Whole Air \#).

Table 1. Decladding and dissolution process in conjunction with air bag collection sequence

\begin{tabular}{|c|c|c|c|c|}
\hline Process & Time. & Date: & $\begin{array}{l}\text { Time } \\
\text { Collected }\end{array}$ & $\begin{array}{l}\text { Day } \\
\text { Collected }\end{array}$ \\
\hline Coating Removal Started & 0348 & $11 / 04 / 96$ & & \\
\hline WA1 & & & 0800 & $11 / 4 / 96$ \\
\hline WA2 & & & 0820 & $11 / 4 / 96$ \\
\hline WA3 & & & 1300 & $11 / 4 / 96$ \\
\hline WA4 & & & 2345 & $11 / 4 / 96$ \\
\hline WAS & & & 0745 & $11 / 5 / 96$ \\
\hline Coating Removal Ended & 2230 & $11 / 05 / 96$ & & $\therefore$ \\
\hline 1st Acid Cut Started (began heating) & 0910 & $11 / 06 / 96$ & & \\
\hline WA6_A\&B & & & 1200 & $11 / 6 / 96$ \\
\hline 1 st Cut at $95 \mathrm{C}$ & 1300 & $11 / 06 / 96$ & $\because$ & 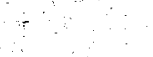 \\
\hline WA7_A\&B & & & 1400 & $11 / 6 / 96$ \\
\hline WA8 & & & 1600 & $11 / 6 / 96$ \\
\hline 1st Acid Ended & 1943 & $11 / 06 / 96$ & & \\
\hline WA9 & & & 2400 & $11 / 6 / 96$ \\
\hline WA10 & & & 0800 & $117 / 96$ \\
\hline 2nd Acid Cut Started (began beating) & 1304 & $11 / 07 / 96$ & & \\
\hline WA11 & & & 1600 & $11 / 796$ \\
\hline 2nd Cut at $95 \mathrm{C}$ & 1730 & $11 / 07 / 96$ & & \\
\hline WA12 & $\therefore$ & & 1800 & $11 / 7 / 96$ \\
\hline WA13 & & & 2000 & $11 / 7 / 96$ \\
\hline WA14 & & & 2400 & $11 \pi / 96$ \\
\hline 2nd Cut Ended & 0001 & $11 / 08 / 96$ & & \\
\hline WA15 & & 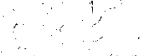 & 0800 & $11 / 8 / 96$ \\
\hline
\end{tabular}

The air samples were delivered to an Nonproliferation Technologies Section (NTS) laboratory at SRTC immediately after collection. The air samples were admitted to a 9.8-meter multipath cell for the analysis using a Fourier transform infrared spectrometer. In most cases, the samples were analyzed approximately two hours after collection. The air samples were analyzed using a Fourier transform infrared spectrometer manufactured by Midac Corporation. The illuminator (Michelson interferometer box) was assembled in an enclosure 
containing a 9.8-meter multipath cell, gold-coated mirrors, and a mercury cadmium telluride (MCT) detector as shown in Figure 1. The interferometer and the multipath cell were equipped with ZnSe optics (beam splitter and windows). The interferometer was warmed for a minimum period of eight hours before the sample analysis to ensure stability. Interferograms were recorded at 0.5 and $2 \mathrm{~cm}^{-1}$ resolutions and converted to single-beam spectra using triangular apodization. A total of 2048 samples were co-added for the $0.5 \mathrm{~cm}^{-1}$ resolution spectra. A total of 512 scans were co-added for the $2 \mathrm{~cm}^{-1}$ resolution spectra. A zero fill of 2 was used in the singlebeam spectra prior to mathematical manipulations. Background interferograms spectra were also recorded at 0.5 and $2 \mathrm{~cm}^{-1}$ resolutions with an evacuated cell ( 2 torr) to obtain the instrument response.

Prior to the air sample analysis, the cell was evacuated with a mechanical pump and flushed several times with dry nitrogen. Approximately 3 liters of the 5-liter Tedlar ${ }^{\mathrm{TM}}$ bag was admitted into the evacuated multipath cell. Samples were analyzed in a period of time up to 3 hours. The period of time was determined by the number of co-added scans $(512,1024,2048)$ and the resolution $\left(0.5 \mathrm{~cm}^{-1}, 2 \mathrm{~cm}^{-1}\right)$ during the data acquisition. Absorbance spectra of the air samples were obtained by using single beam spectra of the sample and the background (evacuated cell). Figure 2 shows a typical absorbance spectrum (WA7).

To identify other spectral features belonging to other compounds, water was spectroscopically removed from the spectra using the wet nitrogen method. In this method, the air sample absorption spectrum is used as a background in real time data acquisition. Nitrogen is bubbled through water and directed to the cell. At the right concentration, most of the water lines are eliminated from the absorption spectrum. At this point, the water spectrum is recorded and used as water reference spectrum for other spectra. Figure 3a shows the absorbance spectrum of WA7 without the water. It is evident in Figure 3a that the absorption bands belonging to $\mathrm{NO}$ and $\mathrm{HNO}_{2}$ were previously obscured by the water absorption bands. Further spectral improvement was obtained by subtracting the canyon air background in air sample WAS as shown in Figure 3b.

During the collection of air samples, the Aerospace group conducted plume imaging experiments by releasing $\mathrm{SF}_{6}$ gas into the annulus of the stack. In these experiments, $\mathrm{SF}_{6}$ gas released in the annulus mixed with the stack air at the top of the stack (approximately $200 \mathrm{ft}$ ). The air sample collection port of the stack is located approximately 100 feet above ground. 'Several absorbance spectra have the $\mathrm{SF}_{6}$ "fingerprint" located at 947 $\mathrm{cm}^{-1}$. The spectra containing $\mathrm{SF}_{6}$ coincide with the introduction of $\mathrm{SF}_{6}$ into the annulus by the Aerospace group. This result lead to the hypothesis that a leak occurred between the annulus and the main stack where the sampling port is located. This condition was later confirmed with engineers familiar with the stack design and modification history. Figure 4 shows a simplified schematic of the F-Canyon stack.

The infrared spectra were analyzed for a variety of chemicals, which included $\mathrm{NO}_{2}, \mathrm{NO}, \mathrm{N}_{2} \mathrm{O}_{5}, \mathrm{~N}_{2} \mathrm{O}_{4}, \mathrm{HNO}_{3}$, $\mathrm{HNO}_{2}, \mathrm{~N}_{2} \mathrm{O}$, and $\mathrm{NH}_{3}$. Only $\mathrm{NO}_{2}, \mathrm{NO}, \mathrm{N}_{2} \mathrm{O}, \mathrm{HNO}_{2}$, and $\mathrm{SF}_{6}$ were clearly identified in the spectra, and their concentrations were quantified using digitized spectra from Infrared Analysis, Inc. Other weak infrared absorption bands were found superimposed on the $\mathrm{HNO}_{2}$ absorption bands at 826 and $808 \mathrm{~cm}^{-1}$. Another spectral feature above the noise level was found at $1718 \mathrm{~cm}^{-1}$. It is not clear the origin of these bands. $\mathrm{NO}_{2}$ has two major absorption bands located at 2907 and $1617 \mathrm{~cm}^{-1}$. The band at $1617 \mathrm{~cm}^{-1}$ is superimposed in a water absorption band and is easily optically saturated at large $\mathrm{NO}_{2}$ concentrations. At large $\mathrm{NO}_{2}$ concentrations, the quantification process was performed using the $2907 \mathrm{~cm}^{-1}$ band. Table 2 shows the vibrational frequencies for the chemical of interests. 
Table 2. Chemicals and their respective vibrational frequencies

\begin{tabular}{|l|l|l|}
\hline Chemical & Vibrational Frequency $\left(\mathrm{cm}^{-1}\right)$ & Detection \\
\hline \hline $\mathrm{NO}_{2}$ & 2907,1617 & Yes \\
\hline $\mathrm{NO}$ & 1876 & Yes \\
\hline $\mathrm{N}_{2} \mathrm{O}$ & 2224 & Yes \\
\hline $\mathrm{HNO}_{3}$ & $895,885,879$ & No \\
\hline $\mathrm{HNO}_{2}$ & $1254,853,791$ & Yes \\
\hline $\mathrm{N}_{2} \mathrm{O}_{4}$ & 1261,750 & No \\
\hline $\mathrm{N}_{2} \mathrm{O}_{5}$ & 1245,743 & No \\
\hline $\mathrm{NH}_{3}$ & 966,931 & No. \\
\hline $\mathrm{SF}_{6}$ & 947 & Yes \\
\hline
\end{tabular}

Air samples were analyzed for ${ }^{85} \mathrm{Kr}$ content by J. R. Cadieux from the Environmental Chemistry Group of Nonproliferation Technologies Section (NTS). F-Canyon stack samples were analyzed by liquid scintillation counting (LSC). A 1.0-ml aliquot of air was removed from each F-Canyon stack gas sample by disposable syringe. The aliquot was transferred to a $25-\mathrm{ml}$ glass LSC vial containing 22 ml of Ultima Gold Extended Range scintillation cocktail through a Teflon-coated, silicone-rubber septum. The head space above the cocktail was evacuated, and the air sample slowly bubbled into the cocktail over a period of 2-3 minutes. The vial was inverted and shaken for several minutes to disperse the air in the cocktail. A 1.0 -ml aliquot of an ${ }^{85} \mathrm{Kr}$ standard demonstrated that the uptake of the activity in the cocktail was quantitative to within plus or minus $5 \%$. A reagent blank was prepared with laboratory air. LSC measurements were made on a Packard TR2 500 counter.

Individual samples and a background (lab air injected into cocktail) were measured for 60 minutes each with counting statistics ranging from 2 to $4 \%$ (two sigma). The counts per minute (cpm) are for a window from 0 to $700 \mathrm{keV}$. The counting efficiency for this energy beta was estimated to be greater than $90 \%$. The quench correction was based on Packard's transformed spectral index of an external Ba-133 standard (tSIE). Sample WA6A was prepared in quadruplicate, and the replicates were counted repeatedly to give counting statistics of 0.3 to $0.4 \%$ (two sigma). Repeated measurements of one of these replicates of a period of a week showed no decrease in counting rate. The average net value was $110 \mathrm{cpm}$ with an RSD of $4 \mathrm{cpm}$. Samples WA13, WA14, and WA15 were reprocessed, and the net activity in WA14 was reproducible and well above counting statistics. Table 3 shows the ${ }^{85} \mathrm{Kr}$ data in disintegrations per minute per $\mathrm{cc}$ of air $(\mathrm{dpm} / \mathrm{cc})$.

\section{Discussion and Results}

The Savannah River Site submitted reports to the South Carolina Health Department of Health and Environmental Control (SCDHEC) that accounts for all chemical releases to the atmosphere from SRS operations. Since the concentrations for many of these chemicals were never measured, an annual estimate was prepared to satisfy the South Carolina law. Several assumptions in the calculations were made to report 
the maximum total annual production of ammonia and NOx for the continuous dissolution of targets. The assumption was made that the dissolver is loaded with 15 metric tons units of MK31A (uranium targets). The cladding removal is approximately completed in 21 hours. The cycle process begins by the removal of the aluminum coating according to the chemical reaction shown below.

$$
\mathrm{Al}+0.70 \mathrm{NaOH}+0.58 \mathrm{NaNO}_{3}+0.11 \mathrm{H}_{2} \mathrm{O} \rightarrow \mathrm{NaAlO}_{2}+0.28 \mathrm{NaNO}_{2}+0.30 \mathrm{NH}_{3}+0.009 \mathrm{H}_{2}
$$

The primary effluents resulting from the decladding process are ammonia and hydrogen. At the F Canyon, the $\mathrm{NH}_{3}$ is released through one of the two 6 -inch diameter stainless steel dissolver stacks. The two dissolver stacks run up the outside of the main stack.

The emission of $\mathrm{NH}_{3}$ per 15 MTU run released to the air is calculated as follows. It is known that 15 MTU contains $856 \mathrm{lb}$ of aluminum. The November 3-8 dissolution was $14.7 \mathrm{MTU}$.

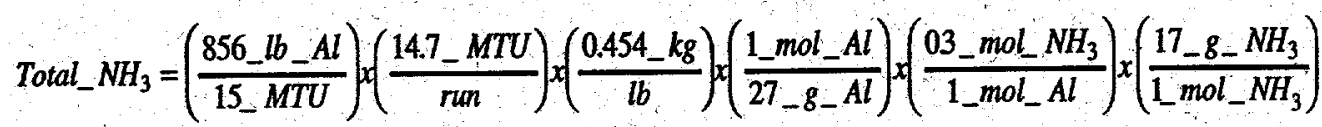

$$
\begin{aligned}
& \text { Total_ } \mathrm{NH}_{3}=\frac{719_{-} \mathrm{kg}_{-} \mathrm{NH}_{3}}{\text { run }}
\end{aligned}
$$

F-Canyon personnel estimated that approximately $240 \mathrm{cfm}$ of air from the dissolver mixes with approximately $900 \mathrm{lb}$ of steam per hour in the dissolver stack. Assuming water vapor at 100 degrees $C$ and using the ideal gas law, the total water vapor volume released to the stack is approximately $6.95 \times 10^{5}$ liters per hour or the equivalent to $409 \mathrm{cfm}$ (water condensation was not taken into account in this calculation). Therefore, the total flow through the dissolver stack is approximately $650 \mathrm{cfm}$. The decladding process occurs in a period of approximately 21 hours. The total production of ammonia during the run is shown below.

$$
\begin{aligned}
& T_{0 t a l} N_{3}=\left(\frac{71.9-k g}{r u n}\right) \times\left(\frac{10^{6}-m g}{k g}\right) \times\left(\frac{1 \_r u n}{21 \_h r}\right) \times\left(\frac{1 \_h r}{60 \_ \text {min }}\right) \times\left(\frac{1-\min }{650 \_f t^{3}}\right) \times\left(\frac{1-f t^{3}}{0.0283-m^{3}}\right) \\
& \text { Total_ } \mathrm{NH}_{3} \approx 3.1 \times 10^{3} \frac{\mathrm{mg}}{\mathrm{m}^{3}} \\
& \text { Total_NH } \approx=\frac{3.1 \times 10^{3} \times 24.45}{17} \approx 4.5 \times 10^{3} \mathrm{ppm}
\end{aligned}
$$

Therefore, for the decladding process of a 14.7 MTU charge, and a time period of 21 hours, a concentration of approximately $4.5 \times 10^{3} \mathrm{ppm}$ was released to the air.

The aluminum cladding removal is followed by the dissolution of the uranium slugs with nitric acid. The uranium slugs are dissolved in a two-step process called the first and second acid cuts. Uranium is dissolved according to the reaction shown below with the production of $\mathrm{NO}$ and $\mathrm{NO}_{2}$.

$$
\mathrm{U}+4.5 \mathrm{HNO}_{3} \rightarrow U \mathrm{UO}_{2}\left(\mathrm{NO}_{3}\right)_{2}+155 \mathrm{NO}+0.87 \mathrm{NO}_{2}+0.05 \mathrm{~N}_{2}+2.25 \mathrm{H}_{2} \mathrm{O}
$$


Further, it is assumed that $\mathrm{NO}$ is readily converted to $\mathrm{NO}_{2}$ in the presence of air as follows:

$2 \mathrm{NO}+\mathrm{O}_{2} \rightarrow 2 \mathrm{NO}_{2}$

14.7 MTU is associated with a minimum of $778 \mathrm{lb}(353 \mathrm{~kg})$ of aluminum. Therefore, the amount of uranium dissolved is $14.35 \mathrm{MT}$ of uranium. The total amount of NOx produced from the uranium is:

$$
\begin{aligned}
& \frac{\text { Maximum_NO } \mathrm{NO}_{2} \text { evolution_(kg) }}{\text { run }}=\left(\frac{14.35 \_\mathrm{MTU}}{\text { run }}\right) \times\left(\frac{1000 \_\mathrm{kg}}{\mathrm{MTU}}\right) x \\
& \left(\frac{1.0 \_\mathrm{mol} \_\mathrm{U}}{0.238 \_\mathrm{kg} \_\mathrm{U}}\right) \times\left(\frac{2.42 \_\mathrm{mol} \_\mathrm{NO}_{2}}{1 \_\mathrm{mol} \_\mathrm{U}}\right) \times\left(\frac{0.046 \_\mathrm{Kg}_{\mathrm{N}} \mathrm{NO}_{2}}{1 \text { mol_NO} \mathrm{NO}_{2}}\right) \\
& =\frac{6.7 x 10^{3} \mathrm{~kg} \_\mathrm{NO}_{2}}{\mathrm{run}}
\end{aligned}
$$

Therefore, $6.7 \times 10^{3} \mathrm{~kg}$ of NOx were produced during the dissolution of 14.35 metric tons of uranium in a charge of 14.7 MTU. The dissolving phase of the uranium fuel was generally completed within 22 hours. The first and second acid cats in the dissolution process used to run back to back with little time between them. Dissolution \#9 shows a large time gap between the acid cuts. The process nowadays last approximately 48 hours. The air flow through the canyon stack is estimated at $240,000 \mathrm{cfm}$. For calculation purposes, assume a constant source of NOx for 48 hours. Therefore, the total NOx released to the air in $\mathrm{mg} / \mathrm{m}^{3}$ for $14.35 \mathrm{metric}$ tons of uranium dissolved in a period of 48 hours with a flow rate of $240,000 \mathrm{~cm}$ is shown below.

$$
\begin{aligned}
& \text { Total_NOx }=\left(\frac{6.7 x 10^{9}-m g_{-} N O x}{r u n}\right) \times\left(\frac{1-r u n}{48 \_h r}\right) \times\left(\frac{1-h r}{60 \_ \text {min }}\right) \times\left(\frac{1-\min }{240,000_{-} f^{3}}\right) \times\left(\frac{1-f^{3}}{0.0283 m^{3}}\right) \\
& \text { Total_NOx }=\frac{3.4 \times 10^{2}-m g}{m^{3}} \\
& \text { Total_NO}(\mathrm{ppm})=\frac{3.4 \times 10^{2} \frac{\mathrm{mg}}{\mathrm{m}^{3}} \Delta 24.45}{46} \\
& \text { Total } \mathrm{NO}_{2}=180 \mathrm{ppm}
\end{aligned}
$$

Sample data of dissolver acid cut solutions show that between 5 to $10 \mathrm{lb}$ of aluminum per MTU remains in the dissolver after coating removal and flushes. In the presence of nitric acid, aluminum is converted to $\mathrm{Al}\left(\mathrm{NO}_{3}\right)_{3}$ following the equation shown below:

$$
\mathrm{Al}+3.75 \mathrm{HNO}_{3} \rightarrow \mathrm{Al}\left(\mathrm{NO}_{3}\right)_{3}+0.23 \mathrm{NO}+0.15 \mathrm{~N}_{2} \mathrm{O}+0.11 \mathrm{~N}_{2}+1.9 \mathrm{H}_{2} \mathrm{O}
$$


where 0.15 moles of $\mathrm{N}_{2} \mathrm{O}$ is produced for every mole of aluminum. Assuming $10 \mathrm{lb}$ of aluminum are left in the solution per every MT, and a charge of $14.7 \mathrm{MTU}$, the total amount of aluminum left in the solution is 147 $\mathrm{lb} /$ run $(66.7 \mathrm{~kg} / \mathrm{run})$. Therefore, the total amount of $\mathrm{N}_{2} \mathrm{O}$ produced during the dissolution is $16.3 \mathrm{~kg} / \mathrm{run}$. The total $\mathrm{N}_{2} \mathrm{O}$ in $\mathrm{mg} / \mathrm{m}^{3}$ and $\mathrm{ppm}$ units released to the air is given below for a 48 -hour period.

$$
\begin{aligned}
& \text { Total_ } \mathrm{N}_{2} \mathrm{O}=\left(\frac{163 \times 10^{6} \_m g}{\operatorname{run}}\right) \times\left(\frac{1-r u n}{48 \_h r}\right) \times\left(\frac{1 \_h r}{60 \_\mathrm{min}}\right) \times\left(\frac{1 \_\mathrm{min}}{240,000 \_\mathrm{ft}^{3}}\right) \times\left(\frac{1 \_\mathrm{ft}^{3}}{0.0283 \_\mathrm{m}^{3}}\right) \\
& =\frac{0.83 \_m g}{m^{3}}
\end{aligned}
$$

Total_ $\mathrm{N}_{2} \mathrm{O}=\frac{0.83 \frac{\mathrm{mg}}{\mathrm{m}^{3}} \times 24.45}{44}=0.46 \mathrm{ppm}$

In summary, the chemical reactions shown above demonstrate and estimate the average concentration in the production of $\mathrm{NO}, \mathrm{NO}_{2}, \mathrm{~N}_{2} \mathrm{O}$, and $\mathrm{NH}_{3}$ during the decladding and dissolving process. Although it is known that the production and therefore the concentration of these effluents is time dependent, for calculation purposes it was assumed that the effluents were released in a constant manner in a time period of 48 hours.

Analyses of air samples with FTIR containing process effluents are hampered to great extent by the water content in the atmosphere. The infrared absorption spectrum of air is dominated by water absorption bands centered around 3700 and $1600 \mathrm{~cm}^{-1}$ and $\mathrm{CO}_{2}$ absorption bands centered at 2348 and $667 \mathrm{~cm}^{-1}$. Some of the compounds of interest in the PUREX process have absorption bands in the spectral locations of the $\mathrm{H}_{2} \mathrm{O}$ and $\mathrm{CO}_{2}$ absorption regions. The detection sensitivities using a 9.8-meter multipath cell for many of these compounds of interest are in the order of $0.01-1 \mathrm{ppm}$.

Figure 5 shows the spectra of $\mathrm{NO}, \mathrm{NO}_{2}, \mathrm{~N}_{2} \mathrm{O}, \mathrm{HNO}_{2}$. The vibrational band of NO located at $1876 \mathrm{~cm}^{-1}$ is the most difficult component to detect and quantify due to the water absorption band. Figure 6, shows a threedimensional plot of the infrared absorption spectra acquired during the decladding and dissolution processes. The spectrum clearly shows the time dependence behavior for several chemicals. Careful examination of the time dependent spectra do not exhibit other time dependent effluents. Methane and $\mathrm{CO}_{2}$ were found to be near ambient concentration levels. The $\mathrm{NO}, \mathrm{NO}_{2}, \mathrm{~N}_{2} \mathrm{O}, \mathrm{HNO}_{2}$, and $\mathrm{SF}_{6}$ were quantified, and the results are shown in Table 3. $\mathrm{Kr}-85$ data is in disintegrations per minute per $1 \mathrm{ml}(\mathrm{dpm} / \mathrm{cc})$ of air above background. 
Table 3. Air samples concentration analysis (ppm). $\mathrm{Kr}-85$ data is in dpm/cc of air

\begin{tabular}{|c|c|c|c|c|c|c|c|c|c|c|}
\hline Sample & $\begin{array}{c}\text { Day } \\
\text { Collected }\end{array}$ & $\begin{array}{l}\text { Time } \\
\text { Collected }\end{array}$ & $\mathrm{NO}_{2}$ & No & $\begin{array}{r}\mathrm{N}_{2} \mathrm{O} \\
\times 100\end{array}$ & $\begin{array}{r}\mathrm{HNO}_{2} \\
\times 100\end{array}$ & $\begin{array}{r}S_{6} \\
\times 500\end{array}$ & (dpm/c & $\begin{array}{l}\mathrm{Kr} \\
\text { (cc) }\end{array}$ & $(2 \sigma)$ \\
\hline WA1 & $11 / 4 / 96$ & 0800 & NM & NM & NM & NM & NM & NM & $+1-$ & NM \\
\hline WA2 & $11 / 4 / 96$ & 0820 & 0 & 0 & 0 & 0 & NM & NM & +1 & NM * \\
\hline WA3 & $11 / 4 / 96$ & 1300 & 0 & 0 & 0 & 0 & NM & 5.4 & $+1-$ & 3.0 \\
\hline WA4 & $11 / 4 / 96$ & 2345 & 0 & 0 & 0 & 0 & NM & 8.6 & +1 & 3.0 \\
\hline WAS & $11 / 5 / 96$ & 0745 & 0 & 0 & 0 & 0 & NM & 6.1 & $+1-$ & 3.0 \\
\hline WA6_A\&B & $11 / 6 / 96$ & 1200 & 153 & 63 & 130 & 100 & 75 & 117.6 & $+1-$ & 4.1 \\
\hline $\begin{array}{l}\text { WA7 } \\
\text { A\&B }\end{array}$ & $11 / 6 / 96$ & 1400 & 84 & 27 & 128 & 120 & 153 & 111.8 & $+1-$ & 4.1 \\
\hline WA8 & $11 / 6 / 96$ & 1600 & 14.3 & 9 & 73 & 15 & 6 & -0.6 & +1 & 2.9 \\
\hline WA9 & $11 / 6 / 96$ & 2400 & 3.4 & NM & 23 & NM & NM & -3.9 & $+1-$ & 2.9 \\
\hline WA10 & $11 / 7 / 96$ & 0800 & 4.2 & NM & 20 & $\mathbf{N M}$ & NM & -5.0 & $+1-$ & 2.8 \\
\hline WA11 & $11 / 7 / 96$ & 1600 & 110 & 38 & 94 & 100 & 159 & 145.0 & $+1-$ & 4.4 \\
\hline WA12 & $11 / 796$ & 1800 & 83 & 6 & 120 & 110 & NM & 155.6 & $+1-$ & 4.5 \\
\hline WA13 & $11 / 7 / 96$ & 2000 & 14 & NM & 96 & NM & NM & -7.2 & +1 & 2.8 \\
\hline WA14 & $11 / 7 / 96$ & 2400 & 9 & NM & 69 & NM & NM & 27.6 & $+1-$ & 3.2 \\
\hline WA15 & $11 / 8 / 96$ & 0800 & 1.4 & NM & 29 & NM & NM & -0.3 & $+1-$ & 2.9 \\
\hline
\end{tabular}

Figure 7 shows a plot concentration versus time for most effiuents identified in Table 3. All the effluents showed a similar behavior for the first and second cuts. WA2, WA3, WA4, and WA5 air samples obtained during decladding process did not show the presence of any particular effluent. For all practical purposes, the air eluting the F-Canyon stack was natural air. Since $\mathrm{NH}_{3}$ or ${ }^{85} \mathrm{Kr}$ was not present in the air samples, it was concluded that good isolation exists between the decladding process pipelines and the pipes leading to the main stack.

Ammonia was previously observed eluting from the dissolver stacks using passive FTIR by NTS. During the decladding phase on September 4, 1996, a Midac instrument in the passive configuration was deployed approximately 6 meters from the stack. The ammonia plume was measured against the skies. Figure 8 show the difference spectrum (plume-sky background) containing the ammonia "fingerprint". During the dissolution \#9, the Aerospace and Army teams clearly identified ammonia from the dissolver stacks.

$\mathrm{NO}_{2}$ was the effluent with the highest concentration detected in the air samples (153 ppm). Since the concentrations were not measured in real time, the $\mathrm{NO}_{2}$ concentration is not necessarily representative of the stack's effluents since NO reacts in the air to produce $\mathrm{NO}_{2}$. The highest concentration of $\mathrm{NO}$ was also found in the first cycle at $63 \mathrm{ppm}$. The highest concentration of $\mathrm{NOx}\left(\mathrm{NO}_{2}+\mathrm{NO}\right)$ was found in the first acid cut at 216 $\mathrm{ppm}$. The $\mathrm{NO}_{2}$ and $\mathrm{NO}$ graphs correlates in time. A close look at these two curves shows that when the $\mathrm{NO}_{2}$ concentration drops in half or less, the NO has mostly disappeared. This effect was seen in the both cuts. 
More information about the correlation of $\mathrm{NO}_{2}$ and $\mathrm{NO}$ will be obtained during the real time studies using an $\mathrm{NO}_{2} / \mathrm{NO}$ analyzer planned for dissolution \#12.

The NOx curves show a large concentration ratio between the peak of the first cut and the valley between the cuts. The concentration of $\mathrm{NO}_{2}$ in WA9 is only 2 to $3 \%$ of the peaks of the first and second acid cuts (WA6 and WA11). NO shows a much wider gap between the cuts. The different width of the gap detected by monitoring $\mathrm{NO}_{2}$ and NO suggests a concentration dependence efficiency of the scrubbers. The average release of NOx to the air for a $14.7 \mathrm{MTU}$ in a period of 48 hours was calculated at $180 \mathrm{ppm}$. The integrated concentration from the experiments show $32 \mathrm{ppm}$ for $\mathrm{NO}_{2}$ and $9 \mathrm{ppm}$ for $\mathrm{NO}$ for total concentration of $\mathrm{NOx}$ of $41 \mathrm{ppm}$. Therefore, approximately $23 \%$ of all NOx is released through the stack to the atmosphere.

$\mathrm{HNO}_{2}$ found in concentrations of $1 \mathrm{ppm}$ correlates with the $\mathrm{NO}_{2}$ profile. At present, it is not clear whether the $\mathrm{HNO}_{2}$ is produced in the stack, the sampler plumbing, or the air bag. This dilemma can only be resolved using non-invasive technologies such as open-path FTIR.

The $\mathrm{N}_{2} \mathrm{O}$ concentration profile is the most interesting of all. $\mathrm{N}_{2} \mathrm{O}$ exists in the atmosphere at approximately between 0.3 to $0.4 \mathrm{ppm}$. The experiments showed $\mathrm{N}_{2} \mathrm{O}$ ambient concentrations of 0.43 to $0.46 \mathrm{ppm}$ in samples WA2, WA3, WA4, and WA5 (background and decladding process). During the dissolution process, $\mathrm{N}_{2} \mathrm{O}$ is produced by aluminum left in the batch reacting with $\mathrm{HNO}_{3}$. It has been estimated that approximately 5 to 10 $\mathrm{lb}$ of aluminum per MTU is left behind in solution. An amount of $10 \mathrm{lb}$ of aluminum per MTU should result in an integrated concentration of $0.46 \mathrm{ppm}$ of $\mathrm{N}_{2} \mathrm{O}$ for a 48 -hour period. The studies indicate that approximately $0.61 \mathrm{ppm}$ of $\mathrm{N}_{2} \mathrm{O}$ was released to the air during the 48 -hour dissolution process. The concentration of $0.61 \mathrm{ppm}$ of $\mathrm{N}_{2} \mathrm{O}$ can be correlated with approximately $199 \mathrm{lb}$ of aluminum left in the dissolver after the decladding process. At a $10 \mathrm{lb}$ of aluminum per MTU, we could estimate from the $\mathrm{N}_{2} \mathrm{O}$ concentration measurement that 20 MTU were dissolved (only 14.7 MTU were dissolved in reality). All these estimates are based on the assumption that the only source for the production of $\mathrm{N}_{2} \mathrm{O}$ is the reaction of aluminum with the $\mathrm{HNO}_{3}$ during the dissolution process.

The concentration measurements also show that the valley to peak concentration of $\mathrm{N}_{2} \mathrm{O}$ is approximately $19 \%$. This ratio is different to the one obtained for $\mathrm{NO}_{2}(3 \%)$ and much larger than the $\mathrm{NO}$ ratio. Since $\mathrm{N}_{2} \mathrm{O}$ is relatively stable and cannot be converted easily to other nitrogen oxides (NO and $\mathrm{NO}_{2}$ to $\mathrm{HNO}_{3}$ ) in the canyon or the atmosphere, the concentration of $\mathrm{N}_{2} \mathrm{O}$ may provide a better indicator for the amount of fuel dissolved at the canyon if the aluminum carryover from decladding is quantified.

The curves of $\mathrm{N}_{2} \mathrm{O}$ versus $\mathrm{NOx}$ and $\mathrm{HNO}_{2}$ are very different. The curves demonstrate that different kinetics are followed in the production of $\mathrm{N}_{2} \mathrm{O}$ and NOx. Since the dissolver is a high-radiation source, a possibility for the photochemical formation of $\mathrm{N}_{2} \mathrm{O}$ from $\mathrm{NOx}$ in the dissolver was considered and eventually eliminated due to the different concentration profiles.

The ${ }^{85} \mathrm{Kr}$ activity profile provided a valuable piece of information in the understanding of the inorganic effluents released from the canyon. The ${ }^{85} \mathrm{Kr}$ profile clearly shows a similarity with the NOx profile and therefore different to the $\mathrm{N}_{2} \mathrm{O}$ profile. The ${ }^{85} \mathrm{Kr}$ concentration profile in the second acid cut is larger than in the first acid cut. The ${ }^{85} \mathrm{Kr}$ profile lags behind the NOx concentration profiles. A burst of ${ }^{85} \mathrm{Kr}$ in air sample WA14 at the present is not understood. Similar ${ }^{85} \mathrm{Kr}$ results were obtained during the repeated analysis of WA13, WA14, and WA15 air bags eliminating the possibility of a measurement error. It is possible that the ${ }^{85} \mathrm{Kr}$ found in WA14 is the result of trapped bubbles in solution or in the pipes and released to the air during the solution transfers. 
Finally, the presence of $\mathrm{SF}_{6}$ was a surprise in these measurements. In a separate but simultaneous experiment, $\mathrm{SF}_{6}$ was released to the annulus by the Aerospace group to image the plume eluting the stack $\mathrm{SF}_{6}$ mixes with the air from the stack at the top of the stack at approximately $200 \mathrm{ft}$ above ground. The sampler is located at approximately $100 \mathrm{ft}$ above the ground. In order to detect $\mathrm{SF}_{6}$ in the samples, the most probable reason is a leak in the inner wall of the stack below the sampling port. Concentrations of $\mathrm{SF}_{6}$ detected in the samples were in the order of $300 \mathrm{ppb}$, which may be used to estimate the leak rate.

\section{Conclusions}

Atmospheric effluent releases of $\mathrm{NO}_{2}, \mathrm{NO}, \mathrm{HNO}_{2}, \mathrm{~N}_{2} \mathrm{O},{ }^{85} \mathrm{Kr}$ and $\mathrm{SF}_{6}$ were identified and quantified during irradiated fuel and target reprocessing operations in the air samples collected at the F-Canyon stack. Concentrations of NOx were well below concentrations predicted by mass balance ( $41 \mathrm{ppm}$ vs. $180 \mathrm{ppm}$ ). The concentration of $\mathrm{N}_{2} \mathrm{O}$ was closer the predicted value $(0.61 \mathrm{ppm}$ versus $0.46 \mathrm{ppm}$ for a $10 \mathrm{lb}$ per. MTU left in the dissolver). The time dependence concentrations of $\mathrm{NO}_{2}, \mathrm{NO}$, and $\mathrm{N}_{2} \mathrm{O}$, although follow the first and second cuts are different, suggesting perhaps a concentration dependence behavior of scrubbers. The $\mathrm{N}_{2} \mathrm{O}$ concentration profile showed a different production kinetics than the NOx concentration profiles. The $\mathrm{N}_{2} \mathrm{O}$ concentration profile obtained in this experiment suggests that it is a better signature for the identification of the amount and type of fuel being dissolved in the canyon. $\mathrm{N}_{2} \mathrm{O}_{4}, \mathrm{~N}_{2} \mathrm{O}_{5}, \mathrm{HNO}_{3}, \mathrm{NH}_{3}, \mathrm{~N}_{2} \mathrm{H}_{4}$ inorganic compounds. were not detected in this study. Other weak infrared absomption bands were found but not identified with any particular effluent. The detection of $\mathrm{SF}_{6}$ added as a plume tracer indicated the presence of a leak in the stack inner wall.

It is important to realize that the integrated concentration values for the effluents are estimates since few points were obtained during the cycle profile. For example, the second acid cut according to operations started on $11 / 7 / 96$ at 1300. The closest points we have are at 800 and 1600 hours. This discrepancy affects the curve and the area under the curve. More studies will be required to accurately determine the profile. 


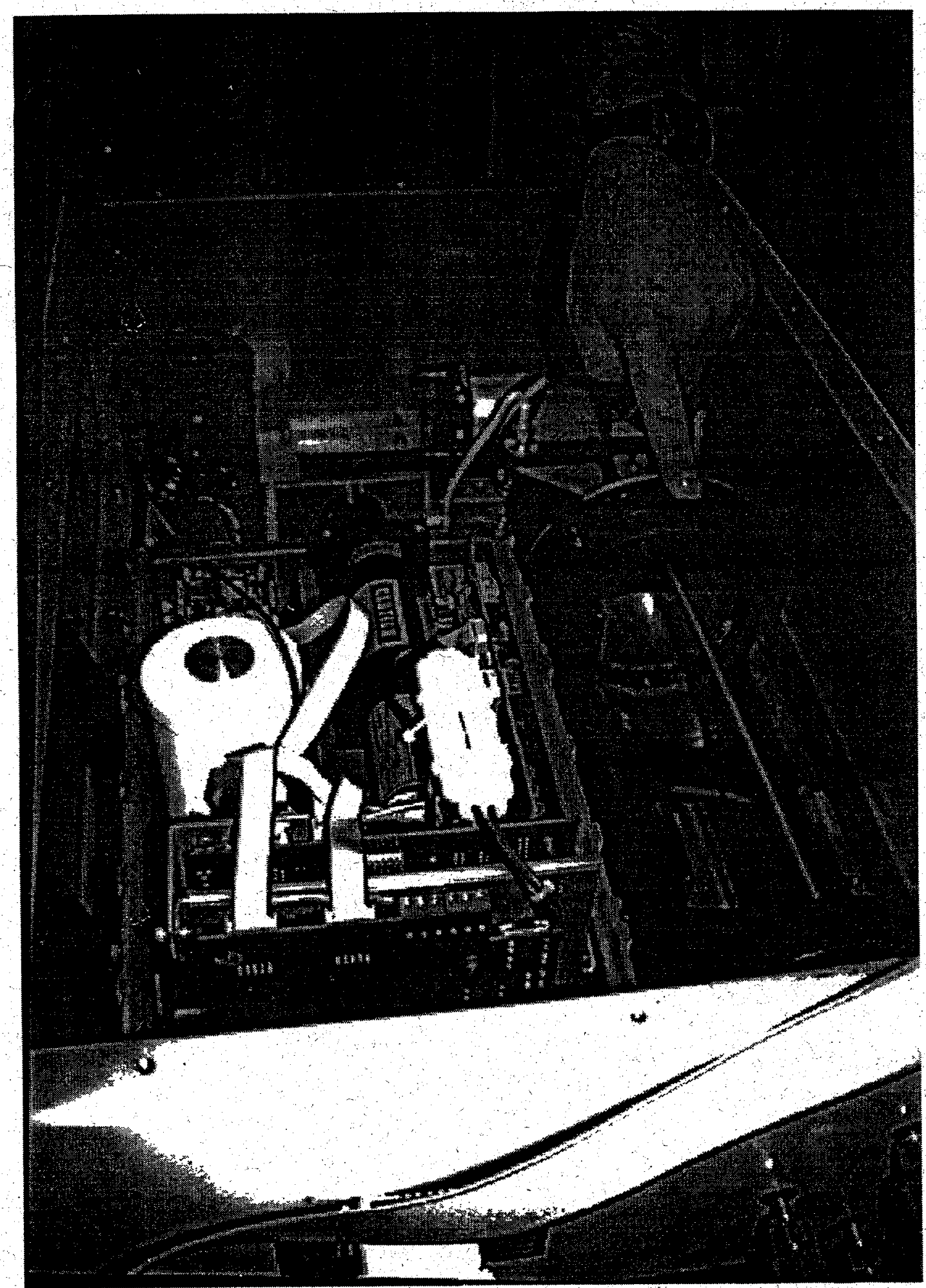

Figure 1. FTIR spectrometer/multipath cell assembly 


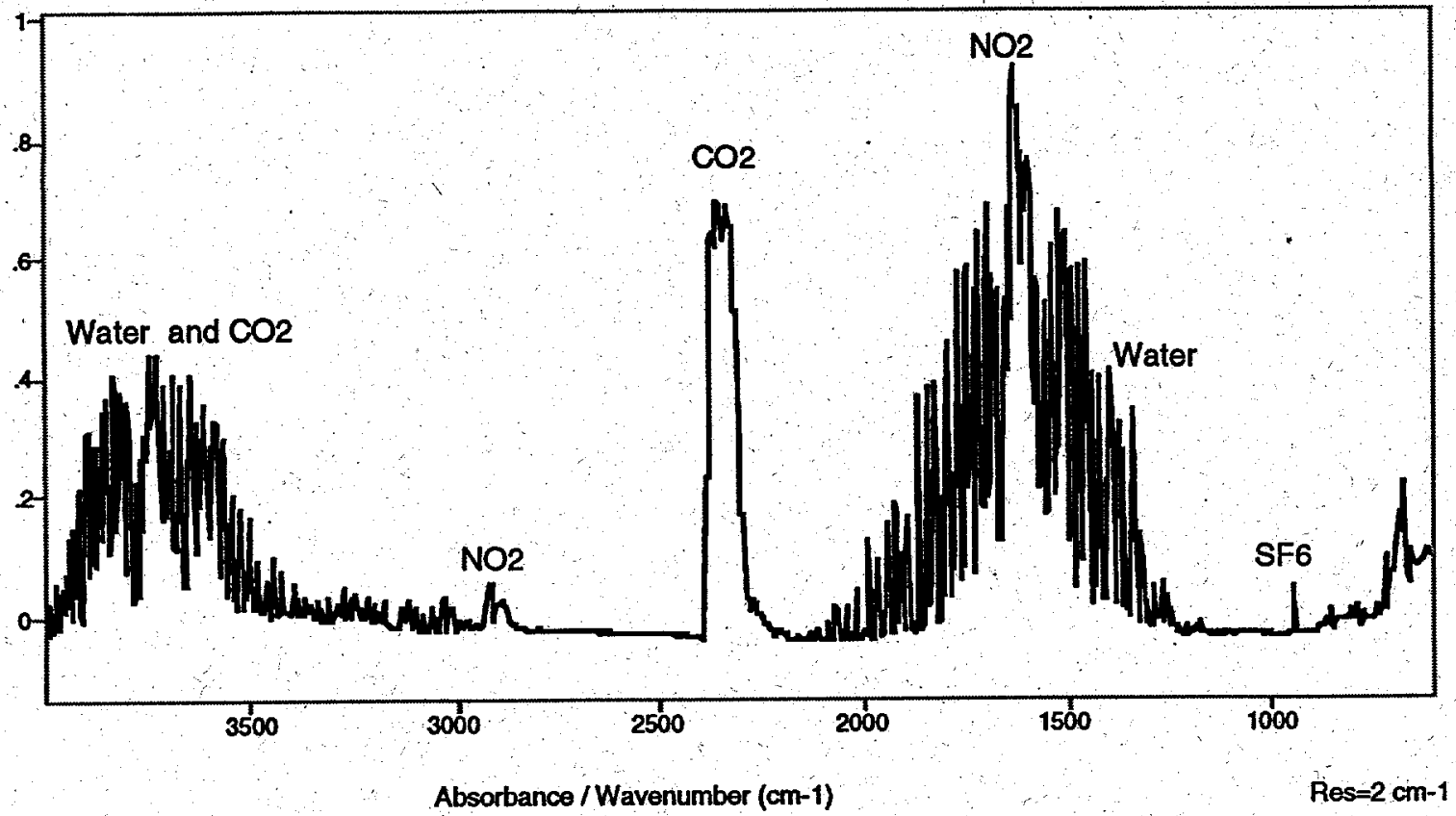

Figure 2. Absorption spectrum of WA7 sample

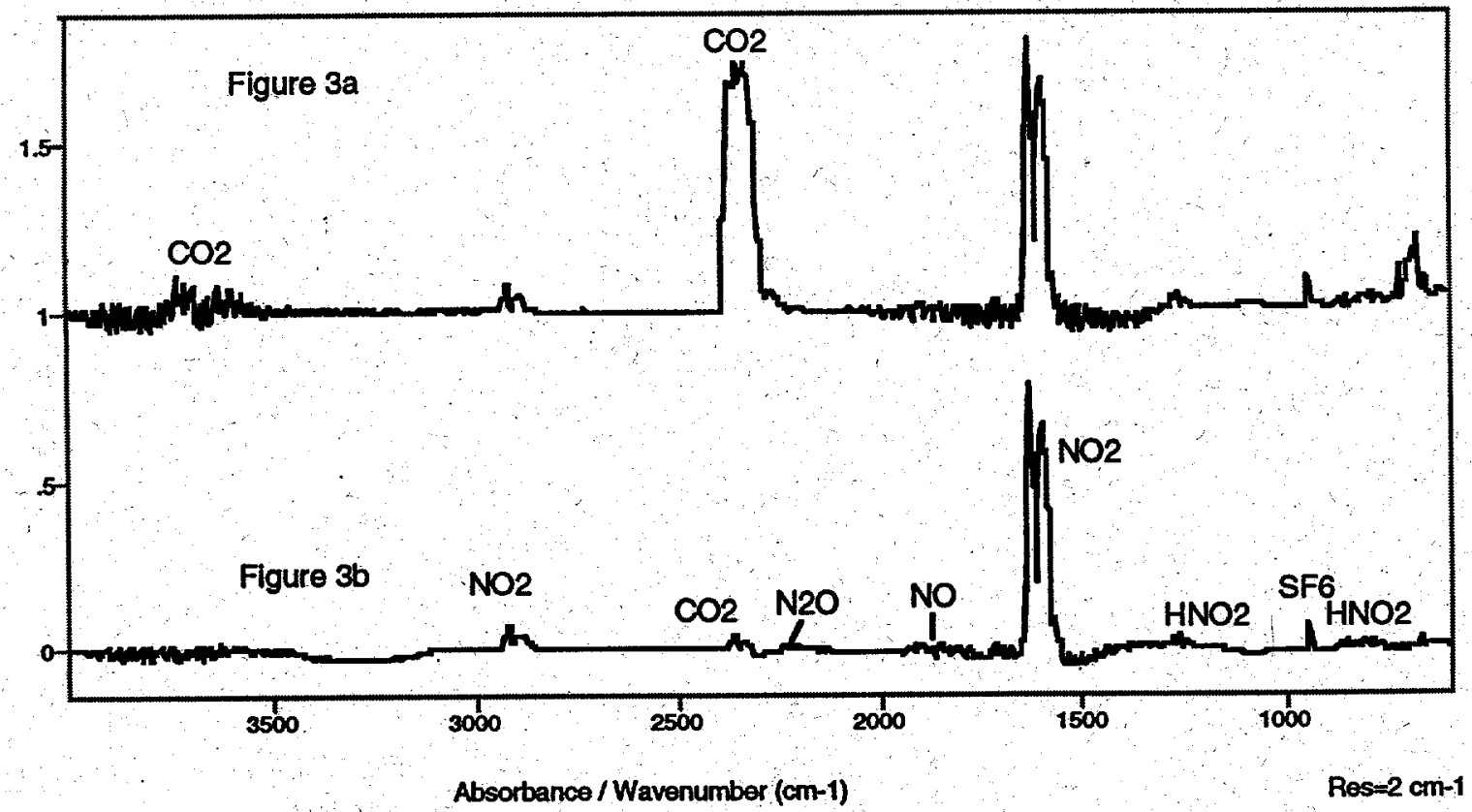

Figures 3a and 3b. Infrared absorption spectra of WA7 sample with water spectroscopically removed and with background subtraction (WA5) 


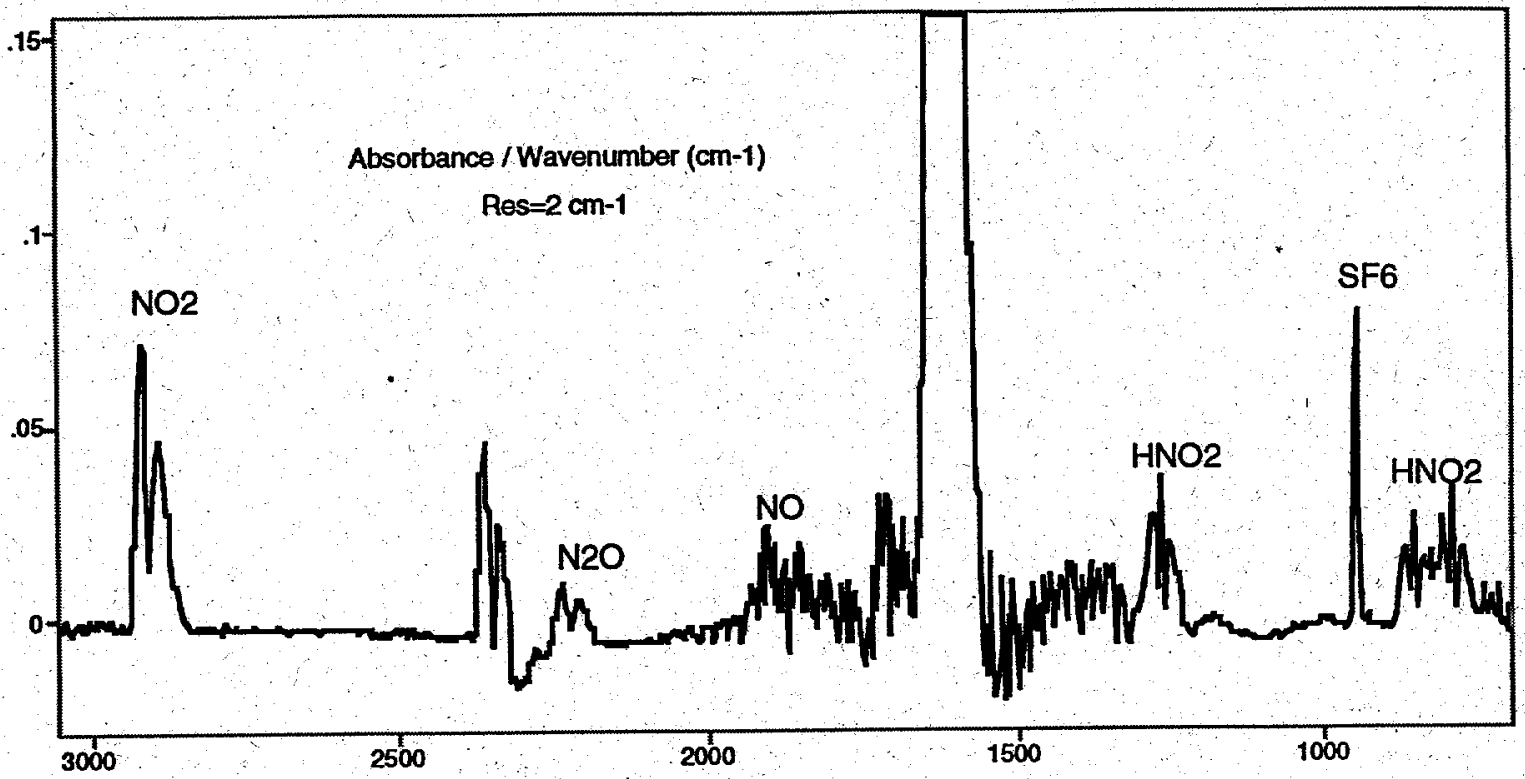

Figure 3c. Amplification of small infrared absorption bands in Figure $3 \mathrm{~b}$

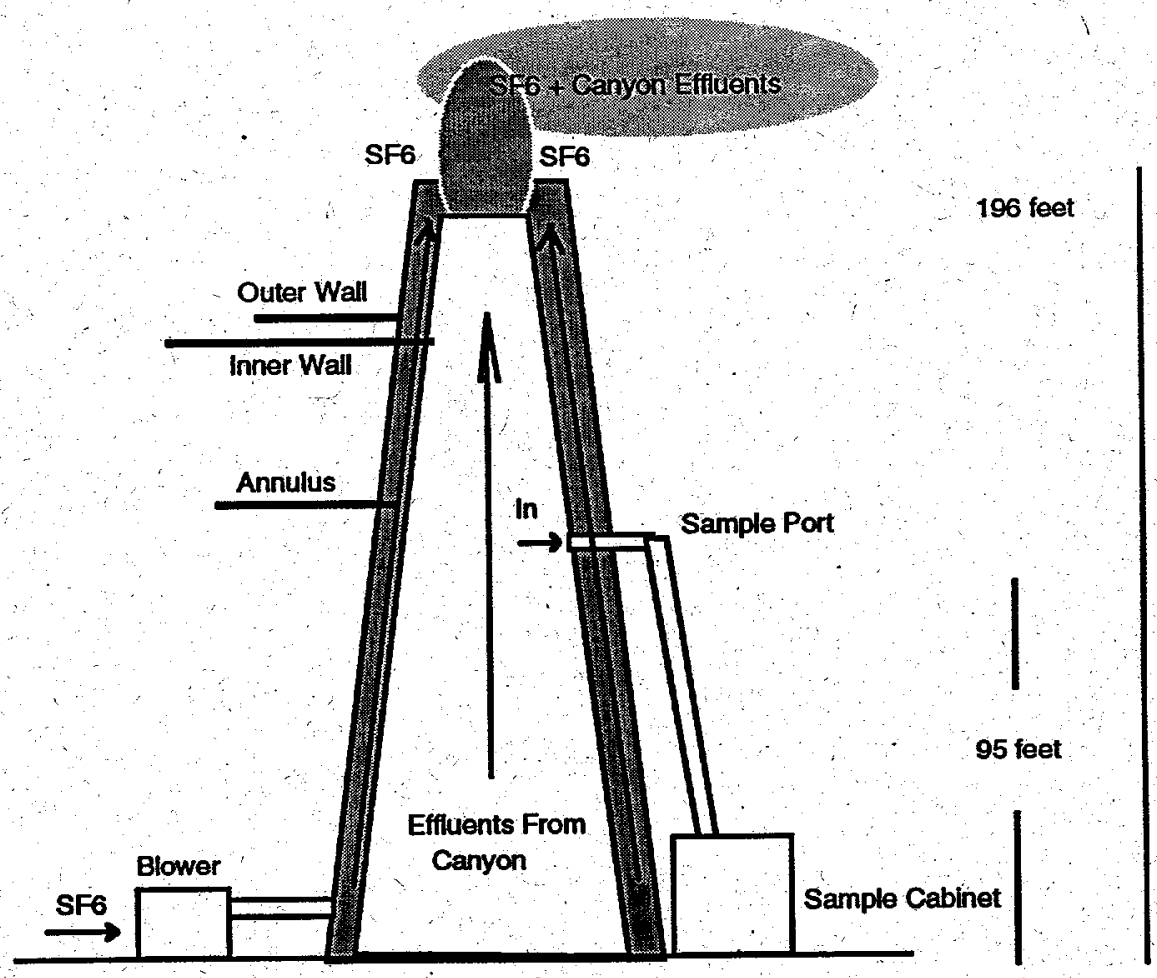

Figure 4. Simplified schematic of F-Canyon stack 


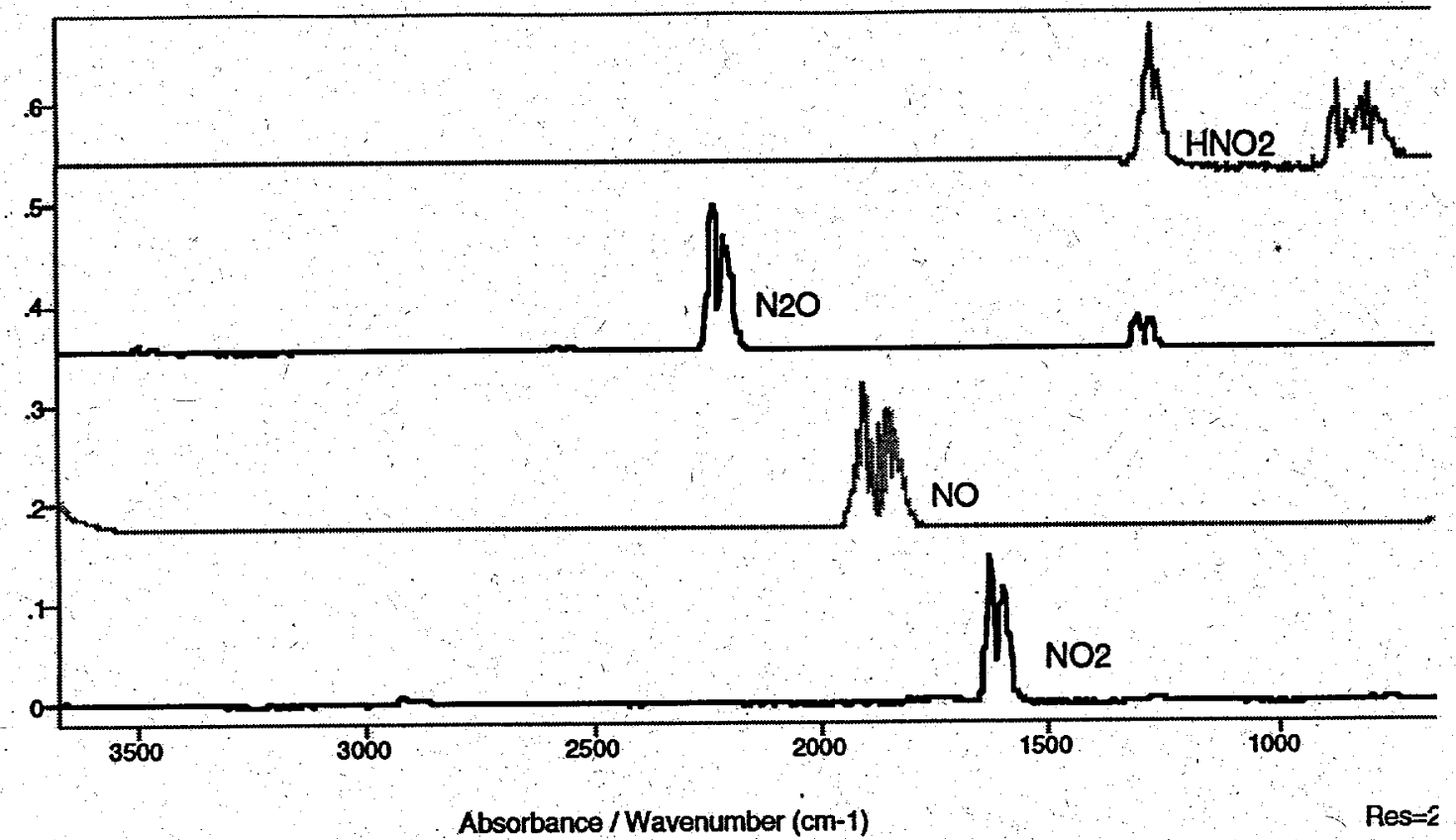

Figure 5. Infrared absorption spectra of $\mathrm{NO}_{2}, \mathrm{NO}, \mathrm{N}_{2} \mathrm{O}$ and $\mathrm{HNO}_{2}$

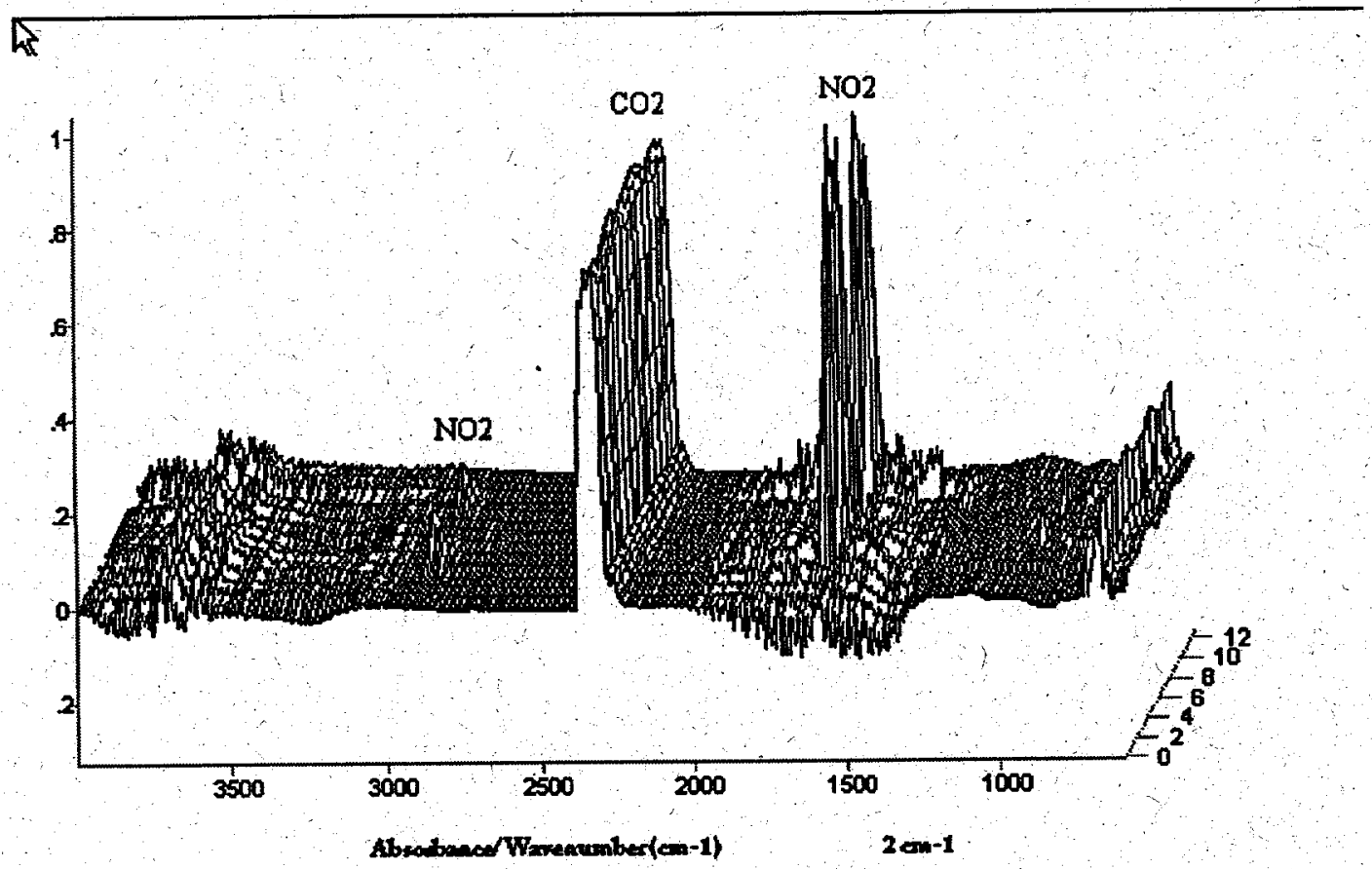

Figure 6. Three-dimensional plot (intensity-wavenumber-time) 


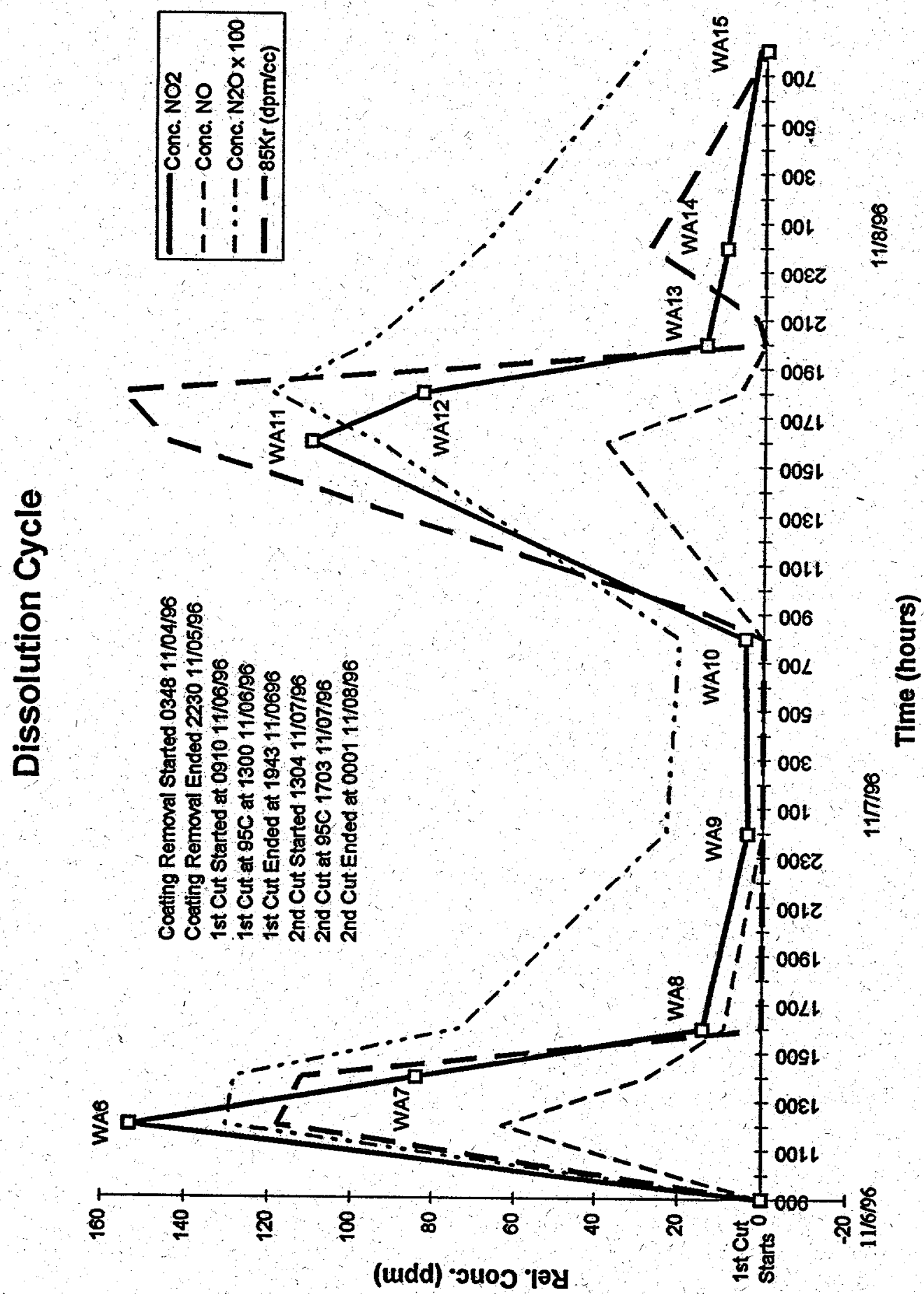

Figure 7. Concentration plot versus time. $\mathrm{Kr}-85$ data is in disintegrations per minute per ml of air (dpm/cc). 


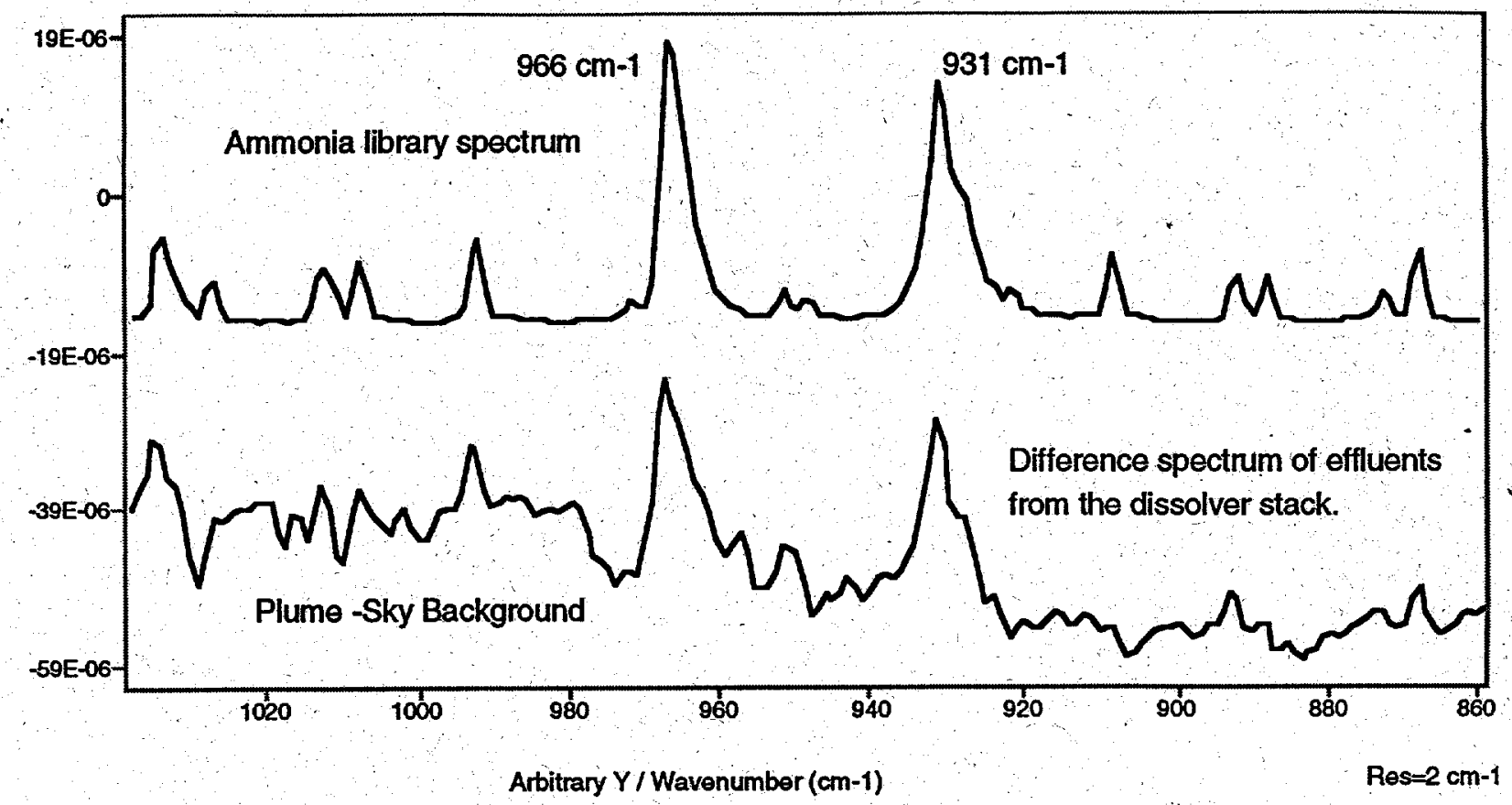

Figure 8. Passive spectrum of ammonia (plume-sky) and library reference 